\title{
NOX4 is an early initiator of neuropathic pain
}

Citation for published version (APA):

Geis, C., Geuss, E., Sommer, C., Schmidt, H. H. H. W., \& Kleinschnitz, C. (2017). NOX4 is an early initiator of neuropathic pain. Experimental Neurology, 288, 94-103.

https://doi.org/10.1016/j.expneurol.2016.11.008

Document status and date:

Published: 01/02/2017

DOI:

10.1016/j.expneurol.2016.11.008

Document Version:

Publisher's PDF, also known as Version of record

Document license:

Taverne

\section{Please check the document version of this publication:}

- A submitted manuscript is the version of the article upon submission and before peer-review. There can be important differences between the submitted version and the official published version of record.

People interested in the research are advised to contact the author for the final version of the publication, or visit the DOI to the publisher's website.

- The final author version and the galley proof are versions of the publication after peer review.

- The final published version features the final layout of the paper including the volume, issue and page numbers.

Link to publication

\footnotetext{
General rights rights.

- You may freely distribute the URL identifying the publication in the public portal. please follow below link for the End User Agreement:

www.umlib.nl/taverne-license

Take down policy

If you believe that this document breaches copyright please contact us at:

repository@maastrichtuniversity.nl

providing details and we will investigate your claim.
}

Copyright and moral rights for the publications made accessible in the public portal are retained by the authors and/or other copyright owners and it is a condition of accessing publications that users recognise and abide by the legal requirements associated with these

- Users may download and print one copy of any publication from the public portal for the purpose of private study or research.

- You may not further distribute the material or use it for any profit-making activity or commercial gain

If the publication is distributed under the terms of Article $25 \mathrm{fa}$ of the Dutch Copyright Act, indicated by the "Taverne" license above, 
Research Paper

\title{
NOX4 is an early initiator of neuropathic pain
}

\author{
Christian Geis ${ }^{\mathrm{a}, \mathrm{b}, *, 1}$, Eva Geuss ${ }^{\mathrm{b}, 1}$, Claudia Sommer ${ }^{\mathrm{a}}$, Harald H.H.W. Schmidt ${ }^{\mathrm{c}}$, Christoph Kleinschnitz ${ }^{\mathrm{b}, \mathrm{d}}$ \\ ${ }^{\text {a } H a n s-B e r g e r ~ D e p a r t m e n t ~ o f ~ N e u r o l o g y ~ a n d ~ C e n t e r ~ o f ~ S e p s i s ~ C o n t r o l ~ a n d ~ C a r e, ~ J e n a ~ U n i v e r s i t y ~ H o s p i t a l, ~ E r l a n g e r ~ A l l e e ~ 101, ~} 07747$ Jena, Germany \\ b Department of Neurology, University Hospital Würzburg, Josef-Schneider Straße 11, 97080 Würzburg, Germany \\ c Department for Pharmacology, Cardiovascular Research Institute, Maastricht University, (CARIM), PO Box 616, Maastricht, 6200 MD, The Netherlands \\ d Department of Neurology, University Hospital Essen, Hufelandstraße 55, 45147 Essen, Germany
}

\section{A R T I C L E I N F O}

\section{Article history:}

Received 1 July 2016

Received in revised form 9 November 2016

Accepted 12 November 2016

Available online 14 November 2016

\section{Keywords:}

NOX4

Chronic constriction injury

Neuropathic pain

GKT136901

\begin{abstract}
A B S T R A C T
Treatment of neuropathic pain remains challenging as the etiology is heterogeneous and pathomechanisms are incompletely understood. One possible mechanism is oxidative stress due to unphysiological reactive oxygen species (ROS) formation. The only know dedicated enzymatic source of ROS are NADPH oxidases of which the type 4 isoform (NOX4) has been suggested to be involved in the subacute and chronic phase of neuropathic pain. Here, we aim to translate this finding into a treatment strategy by examining the efficacy of the NOX1/4specific inhibitor GKT136901 using the chronic constriction injury (CCI) mouse model of neuropathic pain. Unexpectedly, post-nerve lesion treatment using GKT136901 was ineffective to reduce pain-related behavior after CCI. We therefore re-investigated the role of NOX4 using an independent KO mouse model. Early after $\mathrm{CCI}$ we found an increase in pro-inflammatory cytokines, ROS formation and the oxidative stress marker nitrotyrosine in the lesioned nerve together with an upregulated Nox4 gene expression. In NOX4 KO mice, mechanical allodynia was markedly reduced from day 4 after nerve injury as were all ROS related and acute biomarkers. In addition, we observed a reduction in the CCI-induced upregulation of pro-inflammatory cytokines in the sciatic nerve and dorsal root ganglia along with NOX4-deficiency. Thus, we conclude that NOX4 is involved in the development of neuropathic pain states by producing oxidative stress and subsequent cytokine dysregulation at the lesion site. This appears at very early stages immediately after nerve injury explaining ineffectiveness of post-acute pharmacological NOX inhibition. We suggest that future target validation of NOX4 should now focus on defining the possible therapeutic window in human neuropathic pain.
\end{abstract}

(c) 2016 Elsevier Inc. All rights reserved.

\section{Introduction}

Neuropathic pain is a major public health problem that affects approximately $6 \%$ of the adult population worldwide. Despite several therapeutic options, treatment of neuropathic pain remains challenging because of the heterogeneous etiology and the multifactorial mechanisms underlying this disease (Finnerup et al., 2015). Nerve damage induces a complex machinery of pathophysiologic events in the periphery including neuronal hyperexcitability, changes in perineuronal homeostasis, altered gene expression, and the induction of a strong immune response (Rotshenker, 2011). These mechanisms together with secondary events in the central pain processing pathways contribute to the development and maintenance of a steady-state pain condition.

Several studies have indicated that oxidative stress induced by an imbalance in redox homeostasis is critically involved in the induction

\footnotetext{
* Corresponding author at: Jena University Hospital, Hans Berger Department of Neurology, Erlanger Allee 101, 07747 Jena, Germany.

E-mail address: christian.geis@med.uni-jena.de (C. Geis).

1 Equal contribution.
}

of neuropathic pain (Jaggi and Singh, 2011; Kallenborn-Gerhardt et al., 2013; Salvemini et al., 2011). Oxidative stress occurs due to overproduction of free radicals, i.e. reactive oxygen species (ROS) such as superoxide anion $\left(\mathrm{O}_{2}^{-}\right)$or hydrogen peroxide $\left(\mathrm{H}_{2} \mathrm{O}_{2}\right)$ together with a failure of antioxidant defense mechanisms (Altenhöfer et al., 2012). Intracellular accumulation of ROS and disturbances in the cellular redox state are the consequences that then induce not only to general oxidative stress responses like DNA fragmentation, breakdown of signaling pathways, and tissue damage, but also neuronal degeneration and sensitization in pain conditions (Salvemini et al., 2011; Schafer and Buettner, 2001). Accordingly, therapeutically balancing of ROS by the administration of antioxidants or free radical scavengers appears encouraging, but to date, efforts to inhibit ROS have not yielded beneficial effects in pain conditions (Kallenborn-Gerhardt et al., 2013; Schwartz et al., 2008; Steinhubl, 2008; Yowtak et al., 2013). Prevention of ROS generation, rather than scavenging already formed free radicals, represents another possibility to target oxidative stress (Altenhofer et al., 2014; Padi and Kulkarni, 2008).

One source of ROS production is the enzyme family of nicotinamide adenine dinucleotide phosphate (NADPH) oxidases (NOX). Compared 
with other ROS-producing enzymes NOX stand out as ROS generation is their primary function (Altenhofer et al., 2014; Opitz et al., 2007). The rodent genome encodes four genes that contain the catalytic NOX subunit, namely Nox1, Nox2, Nox3, and Nox4 (Altenhöfer et al., 2012). This electron-transferring subunit is constitutively inactive in resting cells and generates ROS only upon activation, e.g. after noxious stimuli (Salvemini et al., 2011). While NOX2 activation is predominantly associated with innate immunity mediated host defense (Lam et al., 2010) and NOX1 with blood pressure control and related vascular mechanisms (Gavazzi et al., 2006), NOX4 was shown highly expressed under ischemic conditions in the central nervous system, e.g. ischemic stroke (Kleinschnitz et al., 2010; Suzuki et al., 2012).

Recent evidence identified activation of NOX as a causative factor that contributes to inflammatory or neuropathic pain role in the peripheral nervous system (Ibi et al., 2008; Kallenborn-Gerhardt et al., 2012, 2014; Kim et al., 2010). Interestingly, NOX4 was reported to be important in the subacute and late-phase of neuropathic pain but to be dispensable for basal sensitivity and for inflammatory pain conditions as evaluated in a NOX4 KO mouse model (Kallenborn-Gerhardt et al., 2012). Injury-induced ROS production as well as subsequent dysmyelination processes of peripheral nerves were identified as the potential underlying mechanisms. Tamoxifen-induced Nox4 gene deletion was effective in reducing pain behavior in late stages of neuropathic pain. Here, we first aimed to evaluate the effect of a pharmacological NOX4 blockade using the NOX1/4 inhibitor GKT136901 in the chronic constriction injury (CCI) mouse model of neuropathic pain. Since postinjury application of GKT136901 was ineffective, we re-investigated the role of NOX4 on neuropathic pain behavior, oxidative stress, and inflammatory processes in a different NOX4 KO model and found NOX4 signaling important for the development of neuropathic pain very early after nerve injury.

\section{Material and methods}

\subsection{Animals}

All animal experiments were approved by local state authorities (Regierung von Unterfranken), comply with the ARRIVE guidelines and were carried out in accordance with the EU Directive 2010/63/EU for animal experiments as well as the German Animal Welfare Act (German Ministry of Agriculture, Health and Economic Cooperation). Experiments were performed on adult male mice at 8-15 weeks of age weighing $25-35 \mathrm{~g}$. The generation of NOX4-deficient (Nox4 ${ }^{-1-}$ ) mice has been described previously (Kleinschnitz et al., 2010). Wild-type (WT) littermates (Nox4 ${ }^{+1+}$ mice) served as controls. Pharmacological inhibition of dual NOX1/4 by the NOX4 inhibitor GKT136901 (Vendrov et al., 2010) was performed in 8-week old male C57BL/6 mice (Charles River Laboratories, Research Models and Services $\mathrm{GmbH}$, Sulzfeld, Germany). Mice were group-housed in boxes in a temperature- and humidity-controlled environment with a 12/12 h lightdark cycle with standard rodent chow and water ad libitum. The minimal number of animals needed to obtain statistical significance was used in the present study to reduce animal numbers and to minimize animal distress. In total, $61 \mathrm{Nox}^{-/-}, 64 \mathrm{Nox}^{+/+}$and $15 \mathrm{C} 57 \mathrm{BL} / 6$ mice were included in the study. For experimental group planning we extrapolated pain levels from large numbers of own previous experiments using the CCI pain model, assumed the pain levels of $\mathrm{Nox}^{-1-}$ mice to $50 \%$, and determined the significance level to 0.05 and the power to 0.8 (beta $=0.2$ ).

\subsection{Chronic constriction injury $(\mathrm{CCI})$}

CCI was performed according to the original description in rats (Bennett and Xie, 1988) modified for mice as reported previously (Schäfers et al., 2003). Surgical procedures were carried out under barbiturate anesthesia using sodium pentobarbital (Merial $\mathrm{GmbH}$,
Hallbergmoos, Germany) at $50 \mathrm{mg} / \mathrm{kg}$ i.p. Briefly, both sciatic nerves were exposed and three ligatures (7-0 prolene) were placed around the right sciatic nerve with $1-\mathrm{mm}$ spacing. Ligatures were tightened until they elicited a brief twitch in the respective hind limb. For sham surgery, sciatic nerves were exposed in the same way but without placing ligatures. Surgeries were performed while being blinded to the experimental groups.

\subsection{Behavioral testing}

Behavioral tests were performed on Day -3 and on Day -1 before CCI to obtain baseline values, and on Days 4, 8, 14, 21, 28, and 35 after $\mathrm{CCI}$. All behavioral testing was done by the same investigator unaware of the treatment and the respective genotypes. For all tests, mice were adapted to the testing environment for at least $1 \mathrm{~h}$ before testing.

\section{a) Assessment of tactile allodynia (von Frey hair-induced paw-withdrawal threshold)}

Mice were individually placed on an elevated metallic wire mesh floor in polyethylene cages. The von Frey filaments (Stoelting Co., Wood Dale, USA) were inserted through the mesh floor and applied to the plantar surface of the hind paw. The force required to bend the hairs ranged from 0.004 to $28.84 \mathrm{~g}$. Hairs were applied six times each on the basis of the up-and-down method as described previously (Chaplan et al., 1994; Geis et al., 2010). The time interval between two trials was at least $1 \mathrm{~min}$ on the same paw and at least $30 \mathrm{~s}$ on the alternate paw. A brisk withdrawal of the paw was considered a positive response. The $50 \%$ withdrawal threshold (i.e. force of the von Frey hair to which an animal reacts in $50 \%$ of the presentations) was recorded.

\section{b) Assessment to thermal hyperalgesia (withdrawal latency to radiant heat)}

The withdrawal latency to heat stimulation was tested using a Plantar Test Instrument (Ugo Basile, Comerio, Italy). The time until the animals reacted with withdrawal to the stimulation by a radiant heat source was determined automatically. Each testing period consisted of a minimum of three presentations for each hind paw. Means of three tests were calculated and taken for further analysis (Geis et al., 2011). The time interval between two trials was at least $1 \mathrm{~min}$. All animals reacted within the $20 \mathrm{~s}$ timeframe of the maximal stimulation period.

\subsection{Pharmacological NOX inhibition and drug delivery}

In a therapeutic approach, we used the small molecule dual NOX1/4 inhibitor GKT136901 (2-(2-chlorophenyl)-4-methyl-5-(pyridin-2-ylmethyl)-1H-pyrazolo[4.3-c]pyridine-3.6(2H,5H)-dione), which was dissolved in $0.5 \%$ carboxymethyl cellulose, $0.25 \%$ polysorbate 20 , and $1 \%$ dimethyl sulfoxide according to previously published protocols (Vendrov et al., 2010). GKT136901 has been shown to reduce ROS generation in vivo when delivered orally in mice (Gaggini et al., 2011; Teixeira et al., 2016; Vendrov et al., 2010). We therefore administered GKT136901 (10 mg/kg once daily) through oral gavage using 20gauge gavage needles beginning from Day 1 after CCI to Day 21. We used C57BL/6 mice, which were randomly selected to receive either GKT136901 or vehicle (i.e. buffer solution without GKT136901). The experimenter treating the animals was blinded to treatment allocation.

\subsection{Euthanasia and tissue processing}

After the final testing or at the indicated time points of tissue analysis, mice were deeply anesthetized using sodium pentobarbital and perfused through the left atrium with $20 \mathrm{ml}$ phosphate-buffered saline (PBS). Bilateral sciatic nerves and L4 and L5 dorsal root ganglia (DRG) as well as lumbar spinal cord were removed. For immunohistochemistry, tissue was then embedded into optimal cutting-temperature compound (TissueTek®, Sakura Finetek Europe B.V., Alphen aan den Rijn, 
The Netherlands) and snap-frozen in isobutene placed in liquid nitrogen. For gene expression analysis, native tissue was saved in RNAlater (QIAGEN GmbH, Hilden, Germany) and immediately stored at $-80^{\circ} \mathrm{C}$ for further processing.

\subsection{Gene expression analysis}

Tissue homogenization, RNA isolation and real-time, quantitative reverse transcription polymerase chain reaction (qRT-PCR) were performed as described previously (Göb et al., 2015; Kleinschnitz et al., 2004). Briefly, total RNA from the ipsilateral sciatic nerve, ipsilateral pooled L4/L5 DRG, and lumbar spinal cord was prepared from Nox $4^{-1-}$ mice and control littermates $\left(\right.$ Nox $\left.^{+/+}\right)$on Days $1,4,8,21$, and 35 after CCI with a Miccra D-8 Homogenizer (ART Prozess- \& Labortechnik $\mathrm{GmbH}$, Müllheim, Germany) using the TRIzol ${ }^{\circledR}$ reagent (Invitrogen GmbH, Darmstadt, Germany) and was quantified spectrophotometrically. Then, $250 \mathrm{ng}$ of total RNA were reverse transcribed with TaqMan ${ }^{\circledR}$ Reverse Transcription Reagents (Applied Biosystems $\mathrm{GmbH}$, Frankfurt, Germany) according to the manufacturer's protocol using random hexamers.

Relative gene expression levels of murine NADPH oxidase 2 (Nox2) (assay ID: Mm01287743_m1, Applied Biosystems), NADPH oxidase 4 (Nox4) (assay ID: Mm00479246_m1, Applied Biosystems), interleukin1 beta (Il-1ß) (assay ID: Mm 00434228_m1, Applied Biosystems), tumor necrosis factor-alpha (Tnf- $\alpha$ ) (assay ID: Mm 00443258_m1, Applied Biosystems), and transforming growth factor-beta1 (Tgf- $\beta 1$ ) (assay ID: Mm 00441724_m1, Applied Biosystems) were quantified with fluorescence TaqMan ${ }^{\circledR}$ technology. GAPDH (TaqMan ${ }^{\circledR}$ Pre-Developed Assay Reagents for Gene Expression, part number: 4352339E, Applied Biosystems) was used as an endogenous control. The PCR was performed with equal amounts of cDNA and water control in the StepOnePlus ${ }^{\mathrm{TM}}$ Real-Time PCR System (Applied Biosystems) using the TaqMan ${ }^{\circledR}$ Universal PCR Master Mix ( $2 \times$ concentration) (Applied Biosystems). Each sample was measured in triplicate and data points were examined for integrity by analysis of the amplification plot. The comparative threshold cycle method was used for relative quantification of gene expression as described previously (Livak and Schmittgen, 2001).

\subsection{Immunohistochemistry and oxidative chemistry biomarkers}

Cryosections $(10 \mu \mathrm{m})$ of the sciatic nerve from Nox $4^{-/-}$mice and control littermates $\left(\mathrm{Nox}^{+/+}\right)$were prepared using a cryostat (Leica Microsystems GmbH, Wetzlar, Germany). For immunohistochemical analysis of reactive nitrogen species (RNS), a rabbit polyclonal antibody to nitrotyrosine (Fisher Scientific GmbH, Schwerte, Germany, EMD Millipore 06284 Cat. 06-284) was applied at a final dilution of 1:100. Sections were incubated at room temperature for $2 \mathrm{~h}$, washed three times for $10 \mathrm{~min}$ in $1 \times$ PBS and incubated at room temperature for 45 min with Cy2-conjugated goat anti-rabbit secondary antibody (1:300, Dianova GmbH, Hamburg, Germany) (Kleinschnitz et al., 2010). For quantification of nitrotyrosine-positive cells per $\mathrm{mm}^{2}$, identical sections from the sciatic nerve were selected and cell counting was performed from four subsequent slices $(40-\mu \mathrm{m}$ distance between slices). The presence of ROS was visualized on cryosections from the sciatic nerves using dihydroethidium (DHE) (D7008, $2 \mu \mathrm{M}$ stock, SigmaAldrich Chemie $\mathrm{GmbH}$, Munich, Germany Sigma). DHE is a fluorescent dye that after reaction with ROS is converted into the red fluorescent compound ethidium, which intercalates into double-stranded DNA. Oxidative cell damage was calculated by measuring the mean fluorescence intensity of oxidized ethidium per nerve section from four subsequent

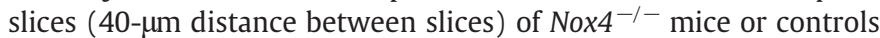
$\left(\mathrm{Nox}^{+/+}\right)$. DNA was counterstained using Hoechst reagent $(33,342$, Sigma-Aldrich Chemie $\mathrm{GmbH}$ ). Negative controls included omission of the primary or secondary antibodies and produced no signal. All sections were viewed and images were acquired with a Nikon Eclipse 50i microscope equipped with the DS-U3 DS camera control unit. Images were analyzed with NIS-Elements software (Nikon Systems, Tokyo, Japan).

\subsection{Statistical analysis}

For statistical analysis SigmaPlot 12.0 (Systat Software GmbH, Erkrath, Germany) was used. The data were tested for normal distribution using the Shapiro-Wilk test. Behavioral data was analyzed using a 2-way repeated measures ANOVA and a post-hoc Holm-Sidak pairwise multiple comparison procedure. Data from the qRT-PCR were analyzed by 2 -way ANOVA with post-hoc Bonferroni adjustment for $P$ values. For histological data, an unpaired, 2-tailed Student's $t$-test was applied. A $P$ value of $<0.05$ was considered statistically significant.

\section{Results}

3.1. Pharmacological NOX4-blockade by GKT136901 is not effective in reducing CCI-induced mechanical allodynia

NOX4 has been reported to contribute to neuropathic pain behavior in the late phase after peripheral nerve injury (Kallenborn-Gerhardt et al., 2012). We tested here whether pharmacological NOX4 inhibition by therapeutic application of the dual NOX1/4 inhibitor GKT136901 (Teixeira et al., 2016; Vendrov et al., 2010) is effective in the CCI mouse model. GKT136901 was applied from Day1 after CCI in 8-week old male $\mathrm{C} 57 \mathrm{BL} / 6$ mice after random allocation to receive either GKT136901 or vehicle. Before CCI, both treatment groups had similar baseline levels of mechanical withdrawal thresholds and heat-induced withdrawal thresholds. Post-injury treatment with GKT136901 did not result in improvement of disease signs (Fig.1). After CCI GKT136901 treated mice had similar mechanical withdrawal thresholds as control mice throughout the entire experimental period beginning from Day 4 after CCI ( $P>0.05$ for Days 4, 8, 14, and 21 after CCI; Fig. $1 \mathrm{~A})$. Withdrawal latencies to radiant heat were also not different between the experimental groups $(P>0.05$ for Days $4,8,14$, and 21 after CCI; Fig. 1B).

\subsection{Nox4 is upregulated in the sciatic nerve and DRG after CCI}

Since we did not find a reduction of $\mathrm{CCl}$-induced hyperalgesia when therapeutic NOX4 inhibition was started after $\mathrm{CCI}$, we next investigated the kinetics of Nox4 gene expression in ipsilateral, proximal sciatic nerve segments, L4/L5 DRG, and lumbar spinal cord from WT mice after CCI or sham surgery from Day 1 to 35 by real-time qRT-PCR analysis. We found a significant increase in Nox4 mRNA after CCI in sciatic nerve on Days 4 $(P<0.05)$ and $8(P<0.01)$, which later decreased to baseline levels. In sham-operated mice, Nox4 mRNA was constitutively expressed at low levels (Fig. 2A). In ipsilateral L4/L5 DRG neurons, we found upregulation of Nox4 mRNA on Day 4 after CCI to levels twofold higher than in shamoperated controls $(P<0.01$; Fig. 2B). In lumbar spinal cord, expression of Nox4 mRNA was unchanged at any time after CCI (Fig. 2C). These data suggest a potential role of NOX4 in the local pathological signaling processes early after nerve damage.

\subsection{Mechanical allodynia after CCI is reduced by NOX4-deficiency}

Since Nox4 mRNA expression is increased early after CCI we then reinvestigated whether and to which time point NOX4 is involved in the generation of neuropathic pain after CCI by using another NOX4-deficient mouse model (Kleinschnitz et al., 2010). Therefore, Nox4 $4^{-1-}$ mice and Nox $4^{+1+}$ littermate controls were tested for pain behavior after CCI. Before CCI, Nox $4^{-1-}$ mice and controls had similar baseline levels of mechanical withdrawal thresholds and heat-induced withdrawal thresholds. After CCI, Nox4 $4^{-/-}$mice had significantly reduced mechanical withdrawal thresholds throughout the entire experimental period beginning from early stages after CCI $(P<0.05$ for Days $4,8,14$, 
A

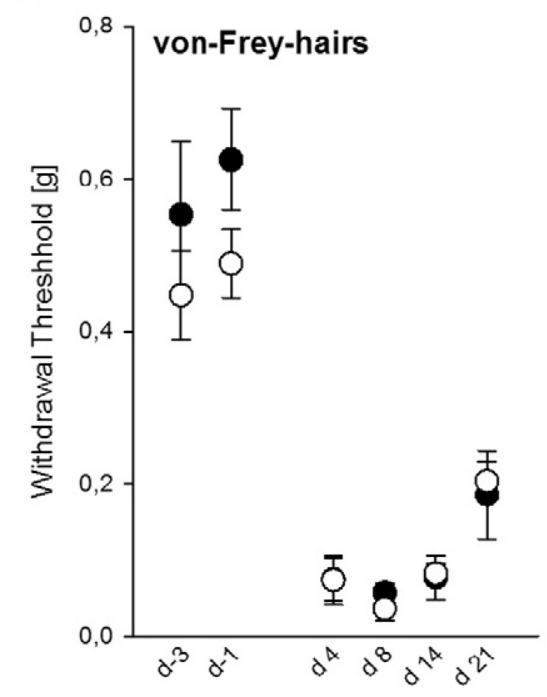

B

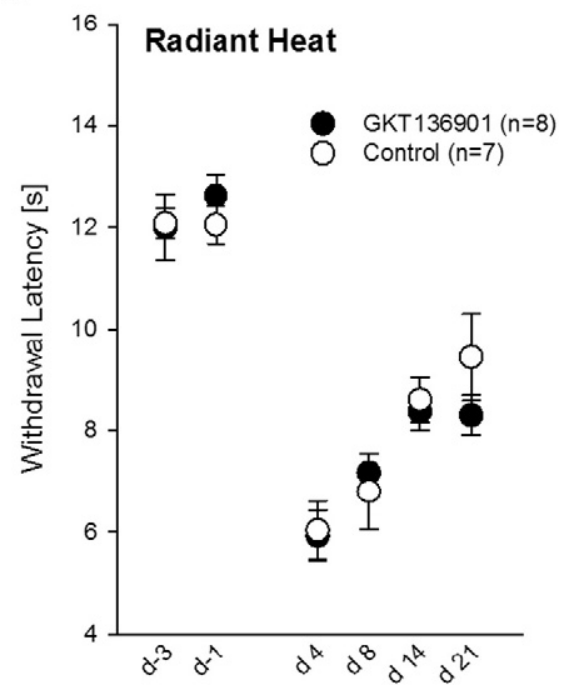

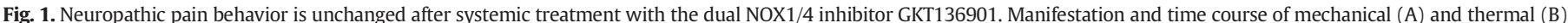

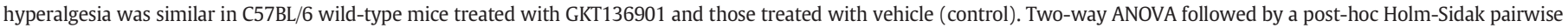
multiple comparison procedure.

21, and 28 after $\mathrm{CCI}$ ). In Nox4 $4^{-1-}$ mice withdrawal thresholds returned to nearly baseline levels on Day 35 after CCI, whereas Nox $4^{+/+}$mice still showed markedly reduced withdrawal thresholds $(P<0.01$ for Day 35; Fig. 3A). Withdrawal latencies to radiant heat were not different between the experimental groups (Fig. 3B). Thus, NOX4 seems to be involved in the early development and maintenance of mechanical allodynia following $\mathrm{CCI}$.

\subsection{CCI-induced expression of NOX2 and proinflammatory cytokine Tnf- $\alpha$ is reduced in Nox4 $4^{-1-}$ mice}

To further elucidate the mechanisms of reduced pain behavior in NOX4-deficient animals, we performed a temporal gene expression profile of NOX2 in the sciatic nerve, ipsilateral DRG, and lumbar spinal cord in NOX4-deficient mice and control littermates $\left(\right.$ Nox $\left.4^{+/+}\right)$after
$\mathrm{CCI}$ and sham surgery. NOX2 is another physiologically relevant NOX isoform that contributes to neuropathic pain hypersensitivity in mice (Kallenborn-Gerhardt et al., 2014; Kim et al., 2010). Further we analyzed prototypic pro- and anti-inflammatory cytokines that are known to be inflammatory markers in the CCI mouse model and that are involved in the induction and maintenance of neuropathic pain (Sommer and Kress, 2004). In Nox $4^{+1+}$ mice, we found that CCI-induced upregulation of Nox2 expression in the sciatic nerve increased to a maximum on Days 4 and 8 after $\mathrm{CCI}$ that was approximately 20 times the value on Day 1 and returned to basal levels at later stages, e.g. Day 21 and $37(P<0.01$ for Day 4; $P<0.001$ for Day 8; Fig. 4). In No $\times 4^{-1-}$ mice, Nox2 mRNA levels were only gradually, but not significantly increased in the sciatic nerve after CCI compared to sham-treated animals. Accordingly, direct comparison between Nox4 $4^{-1-}$ and $\mathrm{Nox} 4^{+/+}$ mice of Nox2 transcription levels after $\mathrm{CCI}$ revealed a remarkable
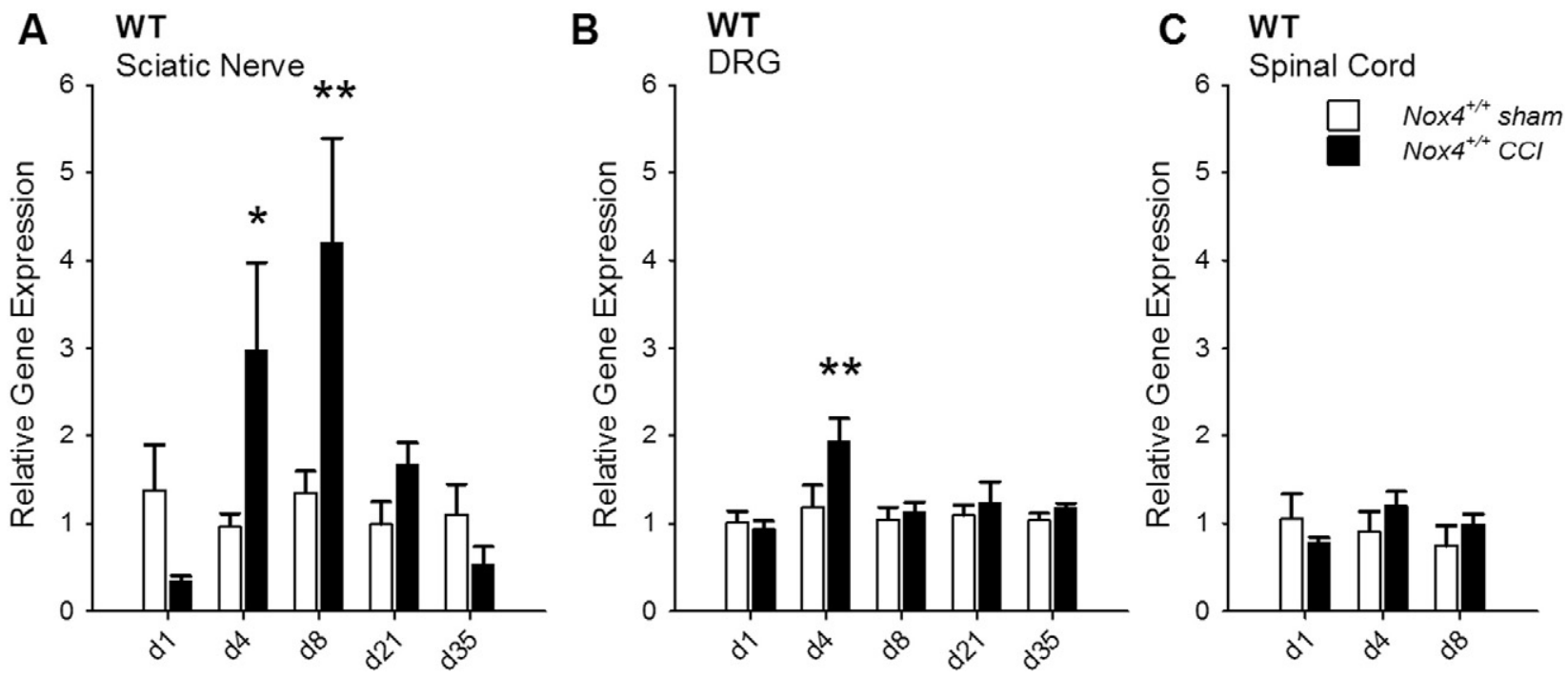

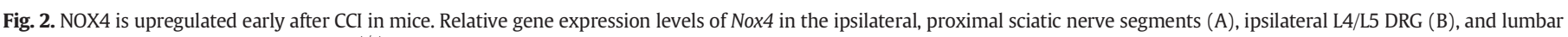

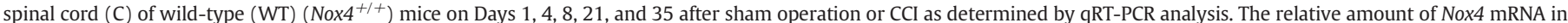

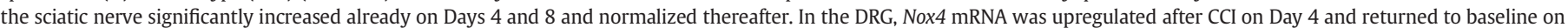

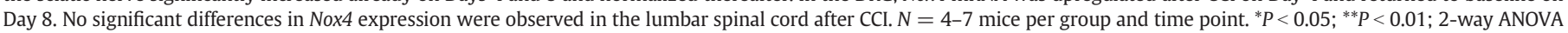
followed by Bonferroni multiple comparison test compared with the control group (sham-operated mice). 
A

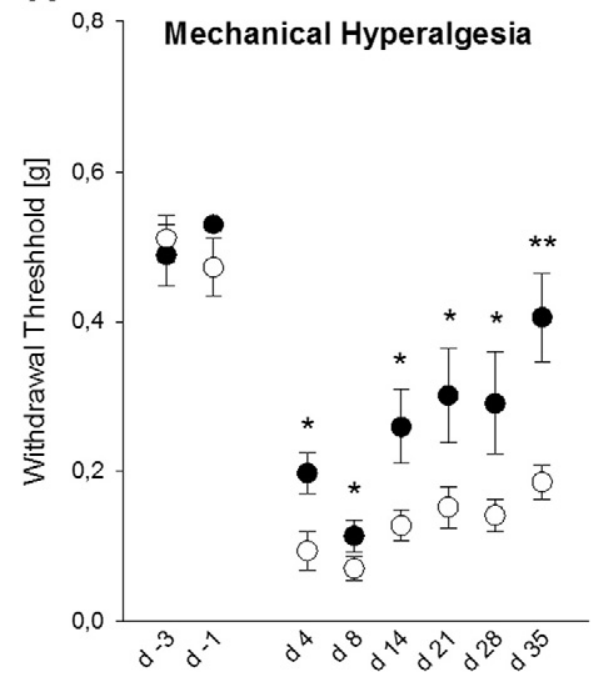

B

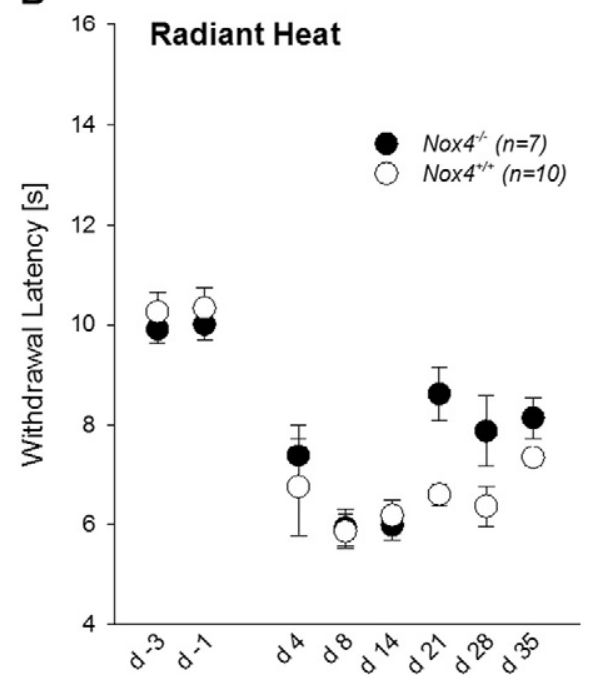

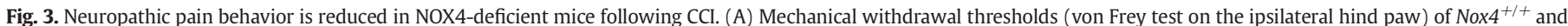

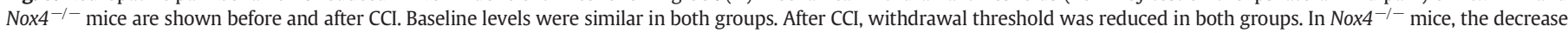

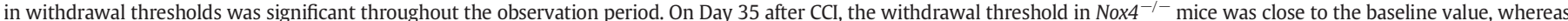

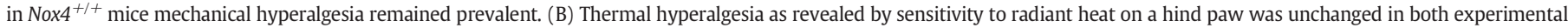
groups. ${ }^{*} P<0.05 ;{ }^{* *} P<0.01 ; 2$-way ANOVA followed by a post-hoc Holm-Sidak pairwise multiple comparison procedure.

\section{Nox2 Gene Expression}
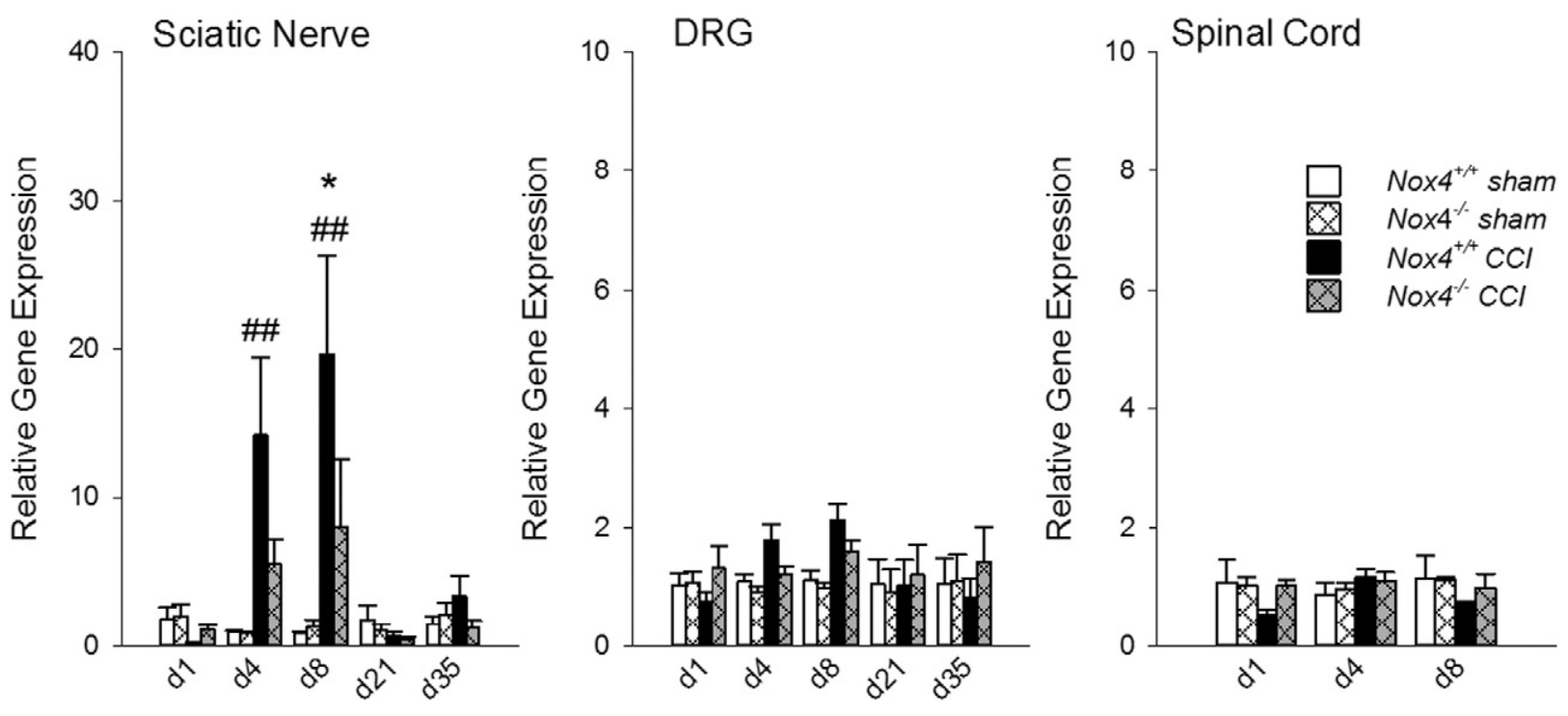

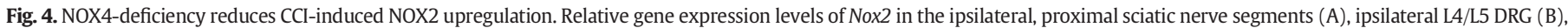

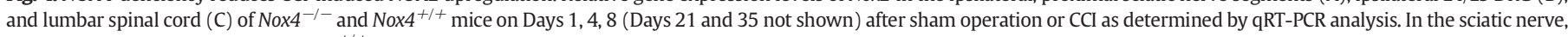

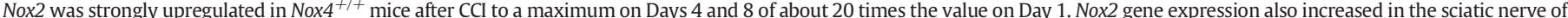

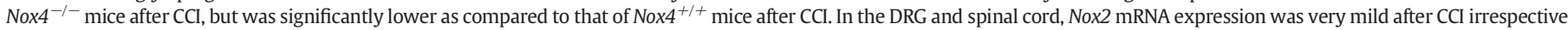

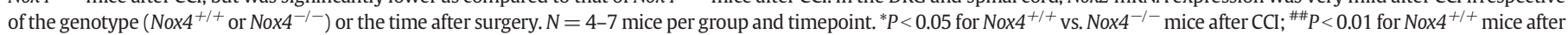
$\mathrm{CCI}$ vs. sham operation; 2-way ANOVA followed by Bonferroni multiple comparison test compared to the respective control group (sham-operated mice or Nox ${ }^{+/+}$mice).

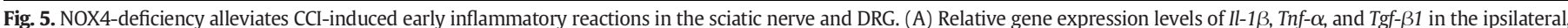

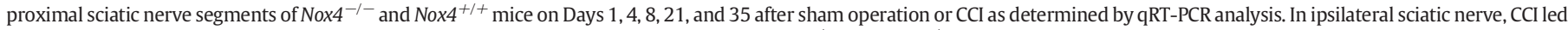

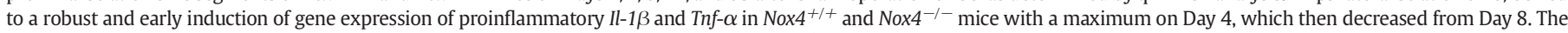

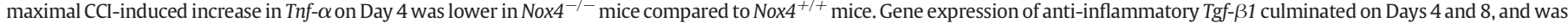

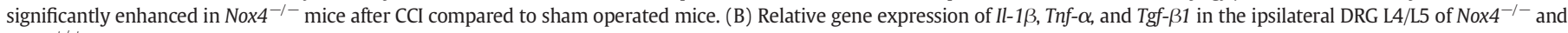

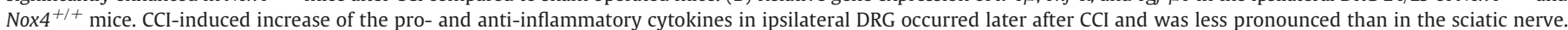

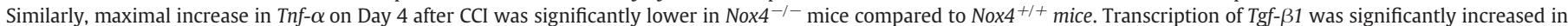

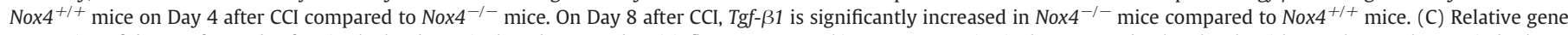

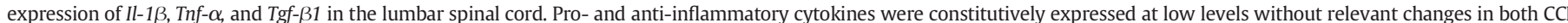

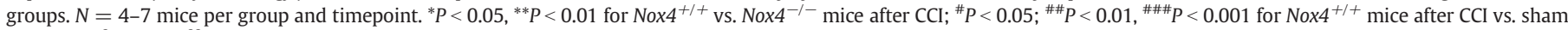

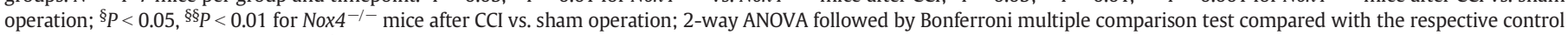
group (sham-operated mice or Nox4 $4^{+1+}$ mice). 
A Sciatic Nerve

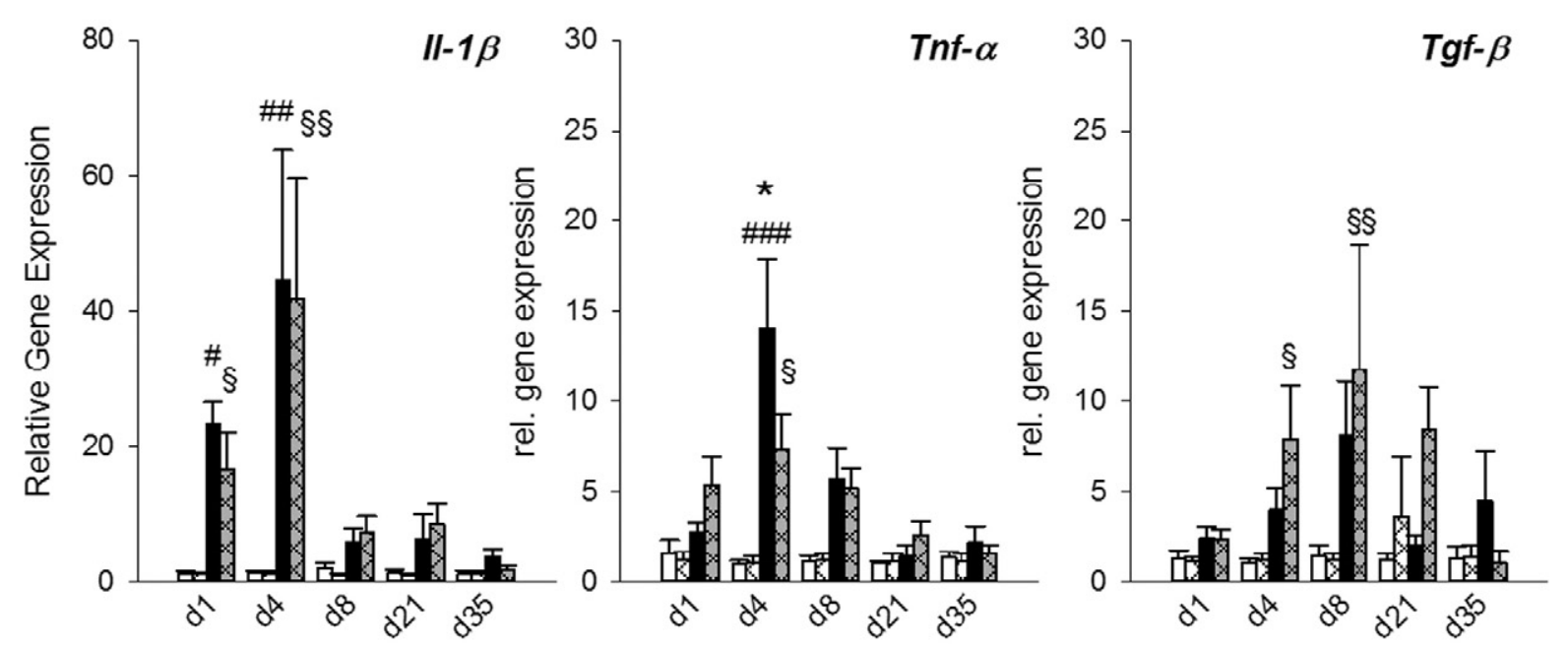

B DRG

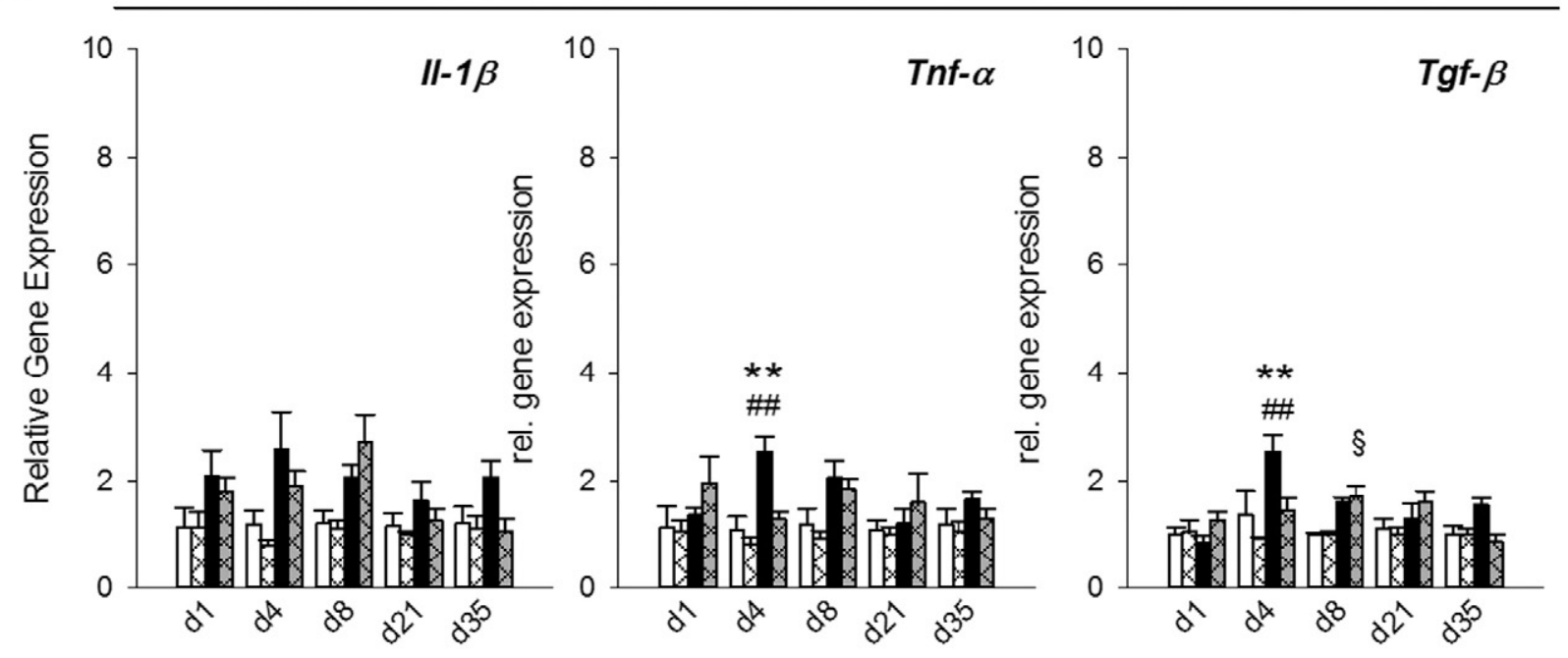

C Spinal Cord

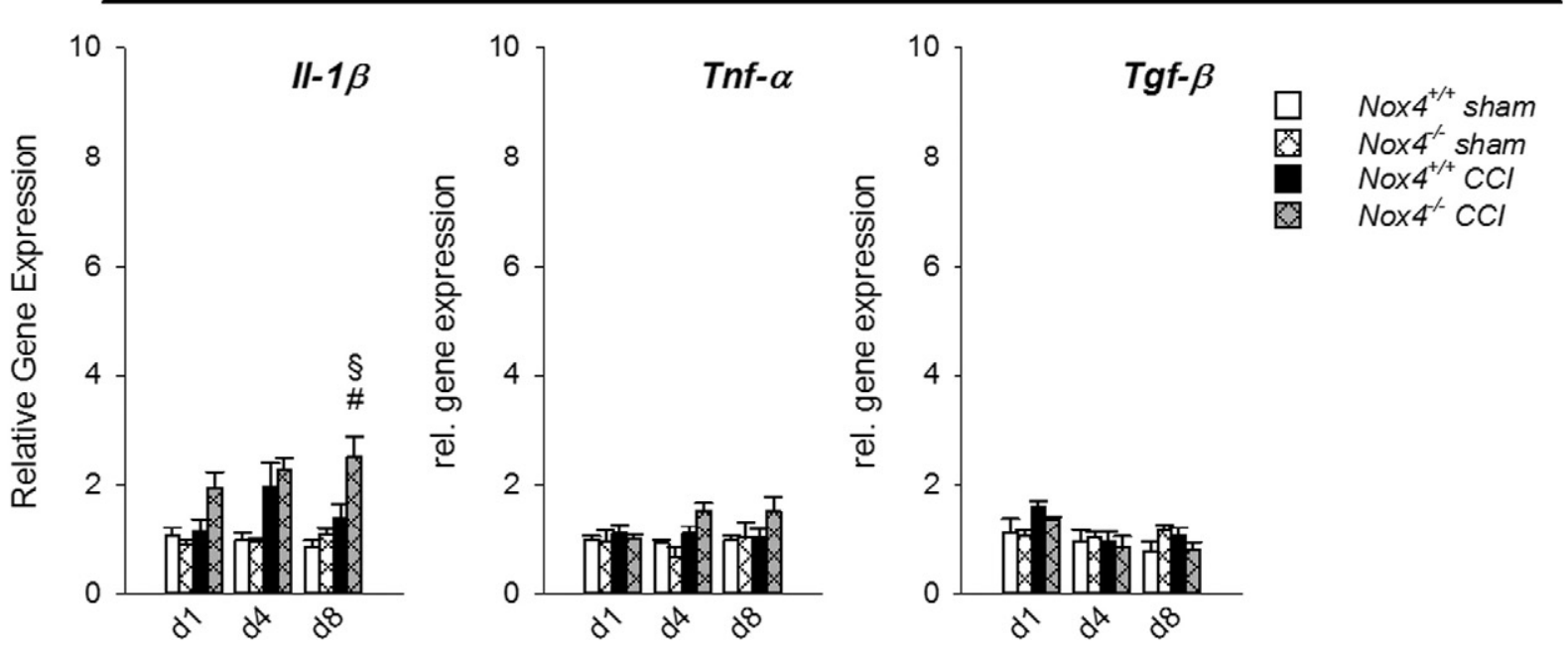


downregulation of Nox2 in the NOX4-deficient mice on Day $8(P<0.05)$. In the DRG or spinal cord we did not observe significant differences between Nox4 $4^{-l-}$ and Nox $4^{+1+}$ mice in the expression of Nox2 mRNA after $\mathrm{CCI}$ or sham operation at any time point (Fig. 4).

Further, $\mathrm{CCI}$ led to an early robust increase in mRNA expression of the proinflammatory cytokines Il-1 $\beta$ and $T n f-\alpha$ in the injured nerve with a maximum on Days 1 and 4 after $\mathrm{CCI}$ and decreasing from Day 8, compared to the sham-operated control groups (Il-1 $\beta$ : $P<0.05$ for Day 1 and $P<0.01$ for Day 4; Tnf- $\alpha$ : $P<0.001$ for Day 4; Fig. 5A). This pattern of upregulation was also present in the DRG but was less pronounced (Tnf- $\alpha: P<0.01$ for Day 4; Fig. 5B). Following CCI, the expression of $I l-1 \beta$ in the sciatic nerve of Nox4 ${ }^{-1-}$ mice was not significantly different to that of $\mathrm{Nox}^{+/+}$mice (Fig. 5A). In contrast, on Day 4 after CCI, the expression of Tnf- $\alpha$ in the sciatic nerve and DRG of Nox $4^{-1-}$ mice was significantly lower as compared to Nox $4^{+/+}$mice $(P<0.05$; Fig. $5 \mathrm{~A}, \mathrm{~B})$. Along with the massive increase in proinflammatory cytokines, we also detected an upregulation of the anti-inflammatory cytokine Tgf- $\beta 1$ on Days 4 and 8 after $\mathrm{CCI}$ in the injured sciatic nerve and DRG (Fig. 5A,B). While Tgf- $\beta 1$ transcription levels in the sciatic nerve did not differ significantly between Nox4 $4^{+/+}$mice subjected to CCI and sham operation, $\mathrm{CCI}$ induced a significant upregulation of anti-inflammatory Tgf- $\beta 1$ in the injured sciatic nerve of NOX4-deficient mice on Days 4 and $8(P<0.01$ for Day 4 and $P<0.05$ for Day 8; Fig. 5A). In lumbar spinal cord, we observed only marginal changes in cytokine expression irrespective of the genotype or time after CCI (Fig. 5C). Thus, NOX4 signaling may be important in the regulation of early modulatory inflammatory processes leading to neuropathic pain development following nerve lesion.

3.5. NOX4-deficiency attenuates oxidative and nitrative stress in the lesioned sciatic nerve in the acute phase after CCI

NOX4 is responsible for the formation of ROS, i.e. superoxide and hydrogen peroxide, which can interact with nitric oxide to form RNS. To assess the generation and involvement of oxidative and nitrative stress in early development of neuropathic pain after CCI we stained crosssections of sciatic nerves to evaluate deposition of DHE and nitrotyrosine, two broad-spectrum indicators of oxidative and nitrative stress (Fig. 6). On Day 1 after CCI, we detected significantly lower amounts of ROS in the sciatic nerve of $N o x 4^{-1-}$ mice compared to Nox $4^{+/+}$mice as quantified by the mean fluorescence intensity of oxidized DHE $(P<0.05$; Fig. $6 \mathrm{~A})$. Since DHE staining may also be a marker for oxidative chemistry events in general, e.g. formation of peroxynitrite and nitration of the amino acid tyrosine, we further analyzed the extent of protein nitration in Nox4 $4^{-/-}$and $N o x 4^{+/+}$mice on Day 1 after CCI. In accordance with reduced DHE detection in the injured nerve of NOX4deficient mice, we also found significantly reduced nitrotyrosine-positive cells in these mice compared to Nox $4^{+/+}$mice $(P<0.05$; Fig. 6B).

\section{Discussion}

The main finding of the study is that the ROS-producing enzyme NOX4 is important in the early generation of neuropathic pain following peripheral nerve lesions in mice by locally generating oxidative stress products very soon after CCI. Deficiency in NOX4 leads to a reduction in of local proinflammatory cytokine upregulation and to an attenuation of mechanical hypersensitivity. Importantly, post-injury pharmacological inhibition of NOX4 after the nerve lesion did not result in any improvement of disease signs, suggesting that NOX4 activation is crucial at the initial stages of neuropathic pain development.

NADPH oxidases were identified as key contributors to oxidative stress and ROS-mediated cell death in pain (Kallenborn-Gerhardt et al., 2012, 2014; Kim et al., 2010) and other neurological disorders such as epilepsy (Williams et al., 2015), brain trauma (Ansari et al., 2014) and stroke (Kleinschnitz et al., 2010). In a spinal nerve transection model NOX2 was responsible for peripheral injury-induced spinal cord microglia activation, ROS formation and subsequent pain hypersensitivity (Kim et al., 2010). NOX2-deficient mice displayed significantly reduced expression levels of the proinflammatory cytokines $I l-1 \beta$ and Tnf- $\alpha$, which is in agreement with our observation of a reduced inflammatory response in NOX4-deficient mice after peripheral nerve injury. Interestingly, in the spinal nerve transection model, Nox2 gene expression was observed not only in dorsal horn neurons but predominantly in spinal cord microglia dependent on toll-like receptor 2 signaling, and nuclear factor- $\mathrm{kB}$ and p38 mitogen-activated protein kinase regulation (Kim et al., 2010; Lim et al., 2013). In contrast, the NOX isoforms 1, 3, and 4 as well as Duox1 and 2, are not expressed in spinal cord microglia following spinal nerve transection (Kim et al., 2010). NOX1 was reported to hold a central function in the development of inflammatory pain by inducing ROS production in DRG neurons leading to enhanced transient receptor potential vanilloid 1 activity and increased sensitivity to painful stimuli (Ibi et al., 2008). In contrast to NOX1, NOX4 was suggested to contribute to the maintenance of neuropathic pain after peripheral nerve injury (Kallenborn-Gerhardt et al., 2014; Kim et al., 2010). In a recent study with a different NOX4 KO mouse model as used here Kallenborn-Gerhardt et al. reported that loss of NOX4 reduced latephase neuropathic pain and that tamoxifen-induced deletion of Nox4 induced analgesia in already existing later pain states in the spared nerve injury (SNI) neuropathic pain mode (Kallenborn-Gerhardt et al., 2012). Based on these findings we tried to evaluate the therapeutic effect of the pharmacological NOX1/4 inhibitor GKT136901 after CCI (Teixeira et al., 2016; Vendrov et al., 2010). Surprisingly, we did not find any effect of systemic NOX1/4 blockade in behavioral analysis. Therefore, we analyzed again the extent and the kinetics of NOX4 signaling and found upregulation of Nox4 gene expression and formation of ROS and RNS very early after CCI. Accordingly, neuropathic pain behavior as well as NOX2 expression and ROS and RNS production was significantly reversed in NOX4 KO mice. Our findings of NOX4 upregulation predominantly at the lesion site in the peripheral nerve and much less in the spinal ganglia and spinal cord point toward a primary role of NOX4 in direct development of neuropathic pain instead of modifying secondary processes of central sensitization in higher pain processing structures. Additionally, we identified a reduction of early local proinflammatory cytokine upregulation as an important beneficial effect of NOX4-deficiency in our CCI model. We observed a reduced expression of proinflammatory cytokines Il- $1 \beta$ and Tnf- $\alpha$, as well as an increased expression of anti-inflammatory Tgf- $\beta$ in the sciatic nerves and DRG from Day 1 to 8 . The reduction of local NOX2 expression and protein nitration in the lesioned nerve was slightly more pronounced than the downregulation of pro-inflammatory cytokines and reduction of neuropathic pain behavior. This is explained as NOX2 signaling and nitrosylation are directly linked to NOX4 deletion which in turn may then influence local inflammation and finally neuropathic pain behavior. It is well established that increased levels of proinflammatory cytokines in the lesioned nerves may change axonal properties, worsen outcome, and thus strengthen chronic pain conditions (Sommer and Kress, 2004). It has been shown in several experimental studies that the acute response in the lesioned nerve is associated with the development of neuropathic pain. Injection of pro-inflammatory cytokines in healthy nerves in equivalent doses to those determined after nerve lesion induce pain behavior (Zelenka et al., 2005) whereas cytokine inhibitors applied locally to the nerve reduce pain behavior (Sommer et al., 2001a, 2001b). Also systemic antagonism of proinflammatory cytokines or administration of anti-inflammatory cytokines reduces neuropathic hyperalgesia in animal models (Schäfers and Sommer, 2007). Importantly, these local inflammatory changes are also observed in humans, e.g. in sural nerve biopsies of patients suffering from painful neuropathy (Empl et al., 2001; Uceyler et al., 2007, 2015).

We used prolene sutures in this mouse model, which results in stable neuropathic pain-related behavior and induces local inflammatory changes as reported previously (Ruscheweyh et al., 2007; Schäfers et al., 2002). The original CCI model was described using chromic gut sutures (Bennett and Xie, 1988). In the past, loose ligatures performed 
A
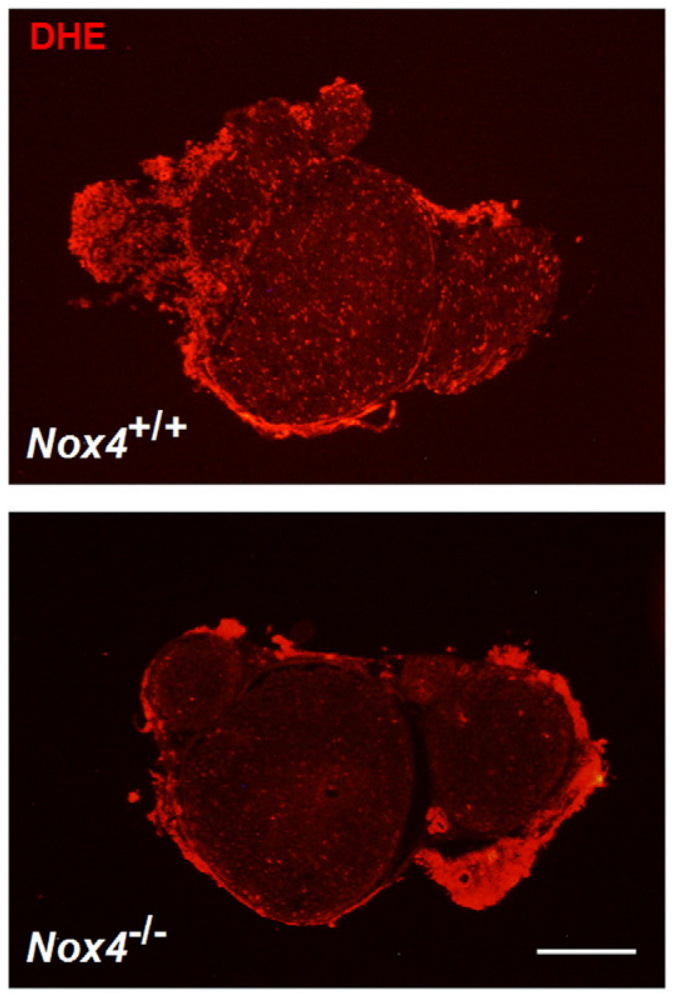

\section{B}
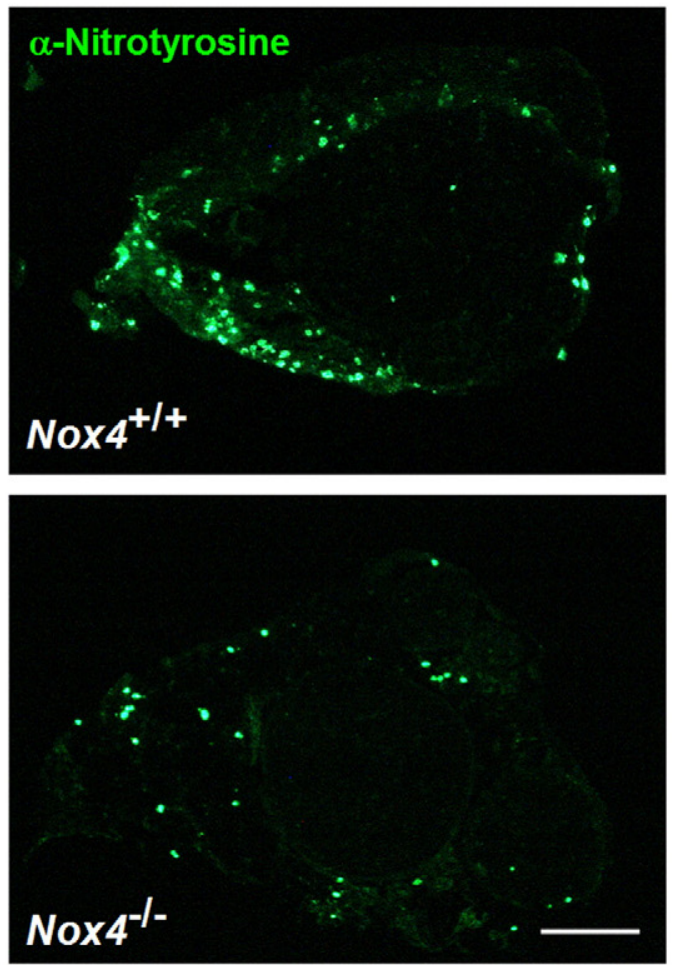
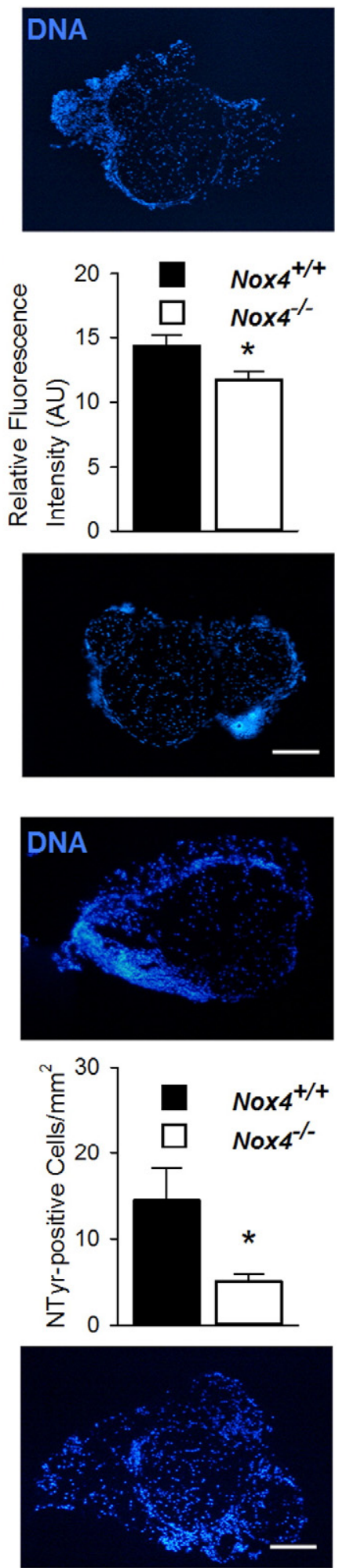

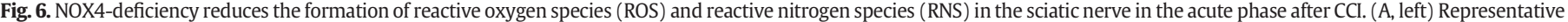

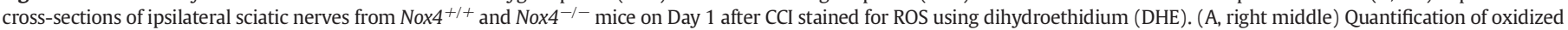

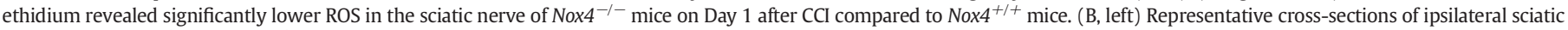

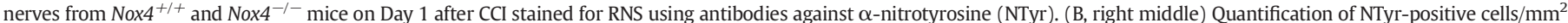

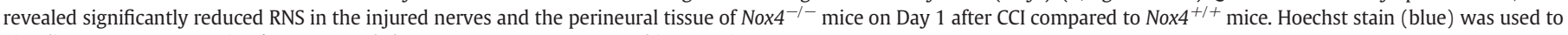
visualize DNA. $N=6-8$ mice. ${ }^{*} P<0.05$. Scale bar represents $200 \mu \mathrm{m}$. AU, arbitrary unit.

with simple (non-chromic) gut and with silk, were shown to be less efficient in inducing pain behavior than chromic gut (Maves et al., 1993). This discrepancy is most likely caused by the technique of tying the ligatures. While we use "loosely constrictive" ligatures that lead to partial Wallerian degeneration of the nerve (Sommer et al., 1993, 1995) no matter which type of ligature is used, others have used very loose 
ligatures, not constricting the nerve, or have simply put chromic gut near the nerve (Maves et al., 1993). In the latter case, a chemical component was implied to interact with the nerve and to induce hyperalgesia. In contrast, if the ligatures are tied in a way to induce actual axonal damage, the type of ligature is less important.

Since post-injury inflammation is a key-mediator of neuropathic pain development and maintenance of the painful condition (Kleinschnitz et al., 2006; Sommer and Kress, 2004), our data support the notion that targeting NOX4 may be a promising therapeutic intervention. Indeed, blocking NOX4 function by genetic deletion or pharmacological inhibition proves to be effective also in other disease models, i.e. in models of atherosclerosis (Vendrov et al., 2010), type 2 diabetes (Sedeek et al., 2013), liver inflammation (Lan et al., 2015), ischemic retinopathy (Deliyanti and Wilkinson-Berka, 2015), and of epithelial ciliary dysfunction in neutrophilic asthma (Wan et al., 2016).

Since we describe importance of NOX4 signaling at early stages in the development of neuropathic pain and others found beneficial effects of NOX4 deletion in another mouse model in late stages of neuropathic pain, we now suggest that future studies should aim to define the importance and to evaluate a possible therapeutic window for a pharmacological approach of NOX4 inhibition in patients with nerve lesions and neuropathic pain. This could be achieved by analysis of nerve biopsies or surgery material after nerve trauma at different stages after injury or neuropathic pain development. Thereafter, animal models with matching time courses of NOX4 regulation, ROS production, cytokine regulation, and development of neuropathic pain should be explored for further pharmacological studies.

In principle, oral delivery of GKT136901 at a dose of $10 \mathrm{mg} / \mathrm{kg}$ once daily from Day 1 to 21 may also be inadequate for our CCI model. However, the dose and timing of application was adapted from previous studies (Vendrov et al., 2010) that proved to be efficient for systemic NOX4 inhibition and showed beneficial effects in atherosclerotic mice. Another theoretical possibility for the ineffectiveness of GKT136901 is that this dual NOX1/4 inhibitor may generally not be suitable for successful treatment of neuropathic pain given that beside NOX1 and 4 also the NOX isoforms 2 is upregulated after pain induction. However, this is relativized by our observation that CCI-induced Nox2 upregulation is impaired in our NOX4 KO mice. We also cannot exclude that pain relief in the NOX4 deficient mice is due to reduction in NOX2 signaling. However, as mentioned above and in contrast to our findings of NOX4 upregulation and cytokine dysregulation in the sciatic nerve, upregulation of Nox2 gene expression is mainly observed in microglia of the spinal cord in neuropathic pain models (Kallenborn-Gerhardt et al., 2014; Kim et al., 2010). Organ- or cell-type specific function is a remarkable prerequisite of the NOX enzymes, especially of NOX4, which is suggested to provoke selective ischemia-reperfusion injury primarily in the brain (Kleinschnitz et al., 2010) and, to a much lesser extent, also in other organs (Braunersreuther et al., 2013; Wilkinson-Berka et al., 2014).

\section{Conclusion}

Our study describes NOX4 as a major contributor to the initiation of neuropathic pain at early stages after nerve lesion. This is accompanied by a combined induction of inflammatory mediators and oxidative stress mechanisms. Since holistic NOX4 blockade per se is beneficial but postacute NOX inhibition seems to be ineffective in neuropathic pain development in this mouse model, future studies should focus on evaluating the role and time course of NOX4 signaling in neuropathic pain in humans to identify possibilities for pharmacological intervention.

\section{Conflicts of interest}

None.

\section{Funding}

This work was supported by the German Federal Ministry of Education and Research (BMBF; Center for Sepsis Control and Care, D3 to CG) and intramural funds of the University of Würzburg, Germany.

\section{Acknowledgements}

We thank L. Biko, B. Dekant, and D. Urlaub for expert technical assistance.

\section{References}

Altenhöfer, S., Kleikers, P.M., Radermacher, K., Scheurer, P., Rob Hermans, J.J., Schiffers, P. Ho, H., Wingler, K., Schmidt, H.H.W., 2012. The NOX toolbox: validating the role of NADPH oxidases in physiology and disease. Cell. Mol. Life Sci. 69, 2327-2343.

Altenhofer, S., Radermacher, K.A., Kleikers, P.W., Wingler, K., Schmidt, H.H., 2014. Evolution of NADPH Oxidase Inhibitors: Selectivity and Mechanisms for Target Engagement (Antioxid Redox Signal).

Ansari, M.A., Roberts, K.N., Scheff, S.W., 2014. A time course of NADPH-oxidase up-regulation and endothelial nitric oxide synthase activation in the hippocampus following neurotrauma. Free Radic. Biol. Med. 77, 21-29.

Bennett, G.J., Xie, Y.K., 1988. A peripheral mononeuropathy in rat that produces disorders of pain sensation like those seen in man. Pain 33, 87-107.

Braunersreuther, V., Montecucco, F., Asrih, M., Pelli, G., Galan, K., Frias, M., Burger, F., Quindere, A.L., Montessuit, C., Krause, K.H., Mach, F., Jaquet, V., 2013. Role of NADPH oxidase isoforms NOX1, NOX2 and NOX4 in myocardial ischemia/reperfusion injury. J. Mol. Cell. Cardiol. 64, 99-107.

Chaplan, S.R., Bach, F.W., Pogrel, J.W., Chung, J.M., Yaksh, T.L., 1994. Quantitative assessment of tactile allodynia in the rat paw. J. Neurosci. Methods 53, 55-63.

Deliyanti, D., Wilkinson-Berka, J.L., 2015. Inhibition of NOX1/4 with GKT137831: a potential novel treatment to attenuate neuroglial cell inflammation in the retina. J. Neuroinflammation 12, 136.

Empl, M., Renaud, S., Erne, B., Fuhr, P., Straube, A., Schaeren-Wiemers, N., Steck, A.J., 2001. TNF-alpha expression in painful and nonpainful neuropathies. Neurology 56 1371-1377.

Finnerup, N.B., Attal, N., Haroutounian, S., McNicol, E., Baron, R., Dworkin, R.H., Gilron, I., Haanpaa, M., Hansson, P., Jensen, T.S., Kamerman, P.R., Lund, K., Moore, A., Raja, S.N., Rice, A.S., Rowbotham, M., Sena, E., Siddall, P., Smith, B.H., Wallace, M., 2015. Pharmacotherapy for neuropathic pain in adults: a systematic review and meta-analysis. Lancet Neurol. 14, 162-173.

Gaggini, F., Laleu, B., Orchard, M., Fioraso-Cartier, L., Cagnon, L., Houngninou-Molango, S Gradia, A., Duboux, G., Merlot, C., Heitz, F., Szyndralewiez, C., Page, P., 2011. Design, synthesis and biological activity of original pyrazolo-pyrido-diazepine, -pyrazine and -oxazine dione derivatives as novel dual Nox4/Nox1 inhibitors. Bioorg. Med. Chem. 19, 6989-6999.

Gavazzi, G., Banfi, B., Deffert, C., Fiette, L., Schappi, M., Herrmann, F., Krause, K.-H., 2006 Decreased blood pressure in NOX1-deficient mice. FEBS Lett. 580, 497-504.

Geis, C., Graulich, M., Wissmann, A., Hagenacker, T., Thomale, J., Sommer, C., Schafers, M., 2010. Evoked pain behavior and spinal glia activation is dependent on tumor necrosis factor receptor 1 and 2 in a mouse model of bone cancer pain. Neuroscience 169, 463-474.

Geis, C., Beyreuther, B.K., Stohr, T., Sommer, C., 2011. Lacosamide has protective disease modifying properties in experimental vincristine neuropathy. Neuropharmacology 61, 600-607.

Göb, E., Reymann, S., Langhauser, F., Schuhmann, M.K., Kraft, P., Thielmann, I., Göbel, K Brede, M., Homola, G., Solymosi, L., Stoll, G., Geis, C., Meuth, S.G., Nieswandt, B. Kleinschnitz, C., 2015. Blocking of plasma kallikrein ameliorates stroke by reducing thromboinflammation. Ann. Neurol. 77, 784-803.

Ibi, M., Matsuno, K., Shiba, D., Katsuyama, M., Iwata, K., Kakehi, T., Nakagawa, T., Sango, K Shirai, Y., Yokoyama, T., Kaneko, S., Saito, N., Yabe-Nishimura, C., 2008. Reactive oxygen species derived from NOX1/NADPH oxidase enhance inflammatory pain. J. Neurosci. 28, 9486-9494.

Jaggi, A.S., Singh, N., 2011. Therapeutic targets for the management of peripheral nerve injury-induced neuropathic pain. CNS Neurol. Disord. Drug Targets 10, 589-609.

Kallenborn-Gerhardt, W., Schroder, K., Del Turco, D., Lu, R., Kynast, K., Kosowski, J., Niederberger, E., Shah, A.M., Brandes, R.P., Geisslinger, G., Schmidtko, A., 2012 NADPH oxidase-4 maintains neuropathic pain after peripheral nerve injury. J. Neurosci. 32, 10136-10145

Kallenborn-Gerhardt, W., Schroder, K., Geisslinger, G., Schmidtko, A., 2013. NOXious signaling in pain processing. Pharmacol. Ther. 137, 309-317.

Kallenborn-Gerhardt, W., Hohmann, S.W., Syhr, K.M., Schroder, K., Sisignano, M., Weigert A., Lorenz, J.E., Lu, R., Brune, B., Brandes, R.P., Geisslinger, G., Schmidtko, A., 2014 Nox2-dependent signaling between macrophages and sensory neurons contributes to neuropathic pain hypersensitivity. Pain 155, 2161-2170.

Kim, D., You, B., Jo, E.K., Han, S.K., Simon, M.I., Lee, S.J., 2010. NADPH oxidase 2-derived reactive oxygen species in spinal cord microglia contribute to peripheral nerve injuryinduced neuropathic pain. Proc. Natl. Acad. Sci. U. S. A. 107, 14851-14856.

Kleinschnitz, C., Brinkhoff, J., Zelenka, M., Sommer, C., Stoll, G., 2004. The extent of cytokine induction in peripheral nerve lesions depends on the mode of injury and NMDA receptor signaling. J. Neuroimmunol. 149, 77-83. 
Kleinschnitz, C., Hofstetter, H.H., Meuth, S.G., Braeuninger, S., Sommer, C., Stoll, G., 2006. T cell infiltration after chronic constriction injury of mouse sciatic nerve is associated with interleukin-17 expression. Exp. Neurol. 200, 480-485.

Kleinschnitz, C., Grund, H., Wingler, K., Armitage, M.E., Jones, E., Mittal, M., Barit, D. Schwarz, T., Geis, C., Kraft, P., Barthel, K., Schuhmann, M.K., Herrmann, A.M., Meuth, S.G., Stoll, G., Meurer, S., Schrewe, A., Becker, L., Gailus-Durner, V., Fuchs, H., Klopstock, T., de Angelis, M.H., Jandeleit-Dahm, K., Shah, A.M., Weissmann, N., Schmidt, H.H.H.W., 2010. Post-stroke inhibition of induced NADPH oxidase type 4 prevents oxidative stress and neurodegeneration. PLoS Biol. 8, e1000479.

Lam, G.Y., Huang, J., Brumell, J.H., 2010. The many roles of NOX2 NADPH oxidase-derived ROS in immunity. Semin. Immunopathol. 32, 415-430.

Lan, T., Kisseleva, T., Brenner, D.A., 2015. Deficiency of NOX1 or NOX4 prevents liver inflammation and fibrosis in mice through inhibition of hepatic stellate cell activation. PLoS One 10, e0129743.

Lim, H., Kim, D., Lee, S.J., 2013. Toll-like receptor 2 mediates peripheral nerve injury-induced NADPH oxidase 2 expression in spinal cord microglia. J. Biol. Chem. 288, 7572-7579.

Livak, K.J., Schmittgen, T.D., 2001. Analysis of relative gene expression data using realtime quantitative PCR and the 2(-Delta Delta C(T)) method. Methods 25, 402-408.

Maves, T.J., Pechman, P.S., Gebhart, G.F., Meller, S.T., 1993. Possible chemical contribution from chromic gut sutures produces disorders of pain sensation like those seen in man. Pain 54, 57-69.

Opitz, N., Drummond, G.R., Selemidis, S., Meurer, S., Schmidt, H.H.H.W., 2007. The 'A's and 'O's of NADPH oxidase regulation: a commentary on "Subcellular localization and function of alternatively spliced Noxo1 isoforms". Free Radic. Biol. Med. 42, 175-179.

Padi, S.S.V., Kulkarni, S.K., 2008. Minocycline prevents the development of neuropathic pain, but not acute pain: possible anti-inflammatory and antioxidant mechanisms. Eur. J. Pharmacol. 601, 79-87.

Rotshenker, S., 2011. Wallerian degeneration: the innate-immune response to traumatic nerve injury. J. Neuroinflammation 8, 109.

Ruscheweyh, R., Forsthuber, L., Schoffnegger, D., Sandkuhler, J., 2007. Modification of classical neurochemical markers in identified primary afferent neurons with Abeta-, Adelta-, and C-fibers after chronic constriction injury in mice. J. Comp. Neurol. 502, 325-336.

Salvemini, D., Little, J.W., Doyle, T., Neumann, W.L., 2011. Roles of reactive oxygen and nitrogen species in pain. Free Radic. Biol. Med. 51, 951-966.

Schafer, F.Q., Buettner, G.R., 2001. Redox environment of the cell as viewed through the redox state of the glutathione disulfide/glutathione couple. Free Radic. Biol. Med. 30, 1191-1212.

Schäfers, M., Sommer, C., 2007. Anticytokine therapy in neuropathic pain management. Expert. Rev. Neurother. 7, 1613-1627.

Schäfers, M., Schmidt, C., Vogel, C., Toyka, K.V., Sommer, C., 2002. Tumor necrosis factoralpha (TNF) regulates the expression of ICAM-1 predominantly through TNF receptor 1 after chronic constriction injury of mouse sciatic nerve. Acta Neuropathol. 104 197-205.

Schäfers, M., Geis, C., Svensson, C.I., Luo, Z.D., Sommer, C., 2003. Selective increase of tumour necrosis factor-alpha in injured and spared myelinated primary afferents after chronic constrictive injury of rat sciatic nerve. Eur. J. Neurosci. 17, 791-804.

Schwartz, E.S., Lee, I., Chung, K., Chung, J.M., 2008. Oxidative stress in the spinal cord is an important contributor in capsaicin-induced mechanical secondary hyperalgesia in mice. Pain 138, 514-524.

Sedeek, M., Gutsol, A., Montezano, A.C., Burger, D., Nguyen Dinh Cat, A., Kennedy, C.R. Burns, K.D., Cooper, M.E., Jandeleit-Dahm, K., Page, P., Szyndralewiez, C., Heitz, F.
Hebert, R.L., Touyz R.M. 2013. Renoprotective effects of a novel Nox1/4 inhibitor in a mouse model of type 2 diabetes. Clin. Sci. 124, 191-202.

Sommer, C., Kress, M., 2004. Recent findings on how proinflammatory cytokines cause pain: peripheral mechanisms in inflammatory and neuropathic hyperalgesia. Neurosci. Lett. 361, 184-187.

Sommer, C., Galbraith, J.A., Heckman, H.M., Myers, R.R., 1993. Pathology of experimental compression neuropathy producing hyperesthesia. J. Neuropathol. Exp. Neurol. 52, 223-233.

Sommer, C., Lalonde, A., Heckman, H.M., Rodriguez, M., Myers, R.R., 1995. Quantitative neuropathology of a focal nerve injury causing hyperalgesia. J. Neuropathol. Exp. Neurol. 54, 635-643.

Sommer, C., Lindenlaub, T., Teuteberg, P., Schafers, M., Hartung, T., Toyka, K.V., 2001a. Anti-TNF-neutralizing antibodies reduce pain-related behavior in two different mouse models of painful mononeuropathy. Brain Res. 913, 86-89.

Sommer, C., Schafers, M., Marziniak, M., Toyka, K.V., 2001b. Etanercept reduces hyperalgesia in experimental painful neuropathy. J. Peripher. Nerv. Syst. 6, 67-72.

Steinhubl, S.R., 2008. Why have antioxidants failed in clinical trials? Am. J. Cardiol. 101, S14-S19.

Suzuki, Y., Hattori, K., Hamanaka, J., Murase, T., Egashira, Y., Mishiro, K., Ishiguro, M., Tsuruma, K., Hirose, Y., Tanaka, H., Yoshimura, S., Shimazawa, M., Inagaki, N., Nagasawa, H., Iwama, T., Hara, H., 2012. Pharmacological inhibition of TLR4-NOX4 signal protects against neuronal death in transient focal ischemia. Sci. Rep. 2, 28.

Teixeira, G., Szyndralewiez, C., Molango, S., Carnesecchi, S., Heitz, F., Wiesel, P., Wood, J.M., 2016. Therapeutic potential of NADPH oxidase $1 / 4$ inhibitors. Br. J. Pharmacol. http:// dx.doi.org/10.1111/bph.13532 (Epub ahead of print).

Uceyler, N., Rogausch, J.P., Toyka, K.V., Sommer, C., 2007. Differential expression of cytokines in painful and painless neuropathies. Neurology 69, 42-49.

Uceyler, N., Riediger, N., Kafke, W., Sommer, C., 2015. Differential gene expression of cytokines and neurotrophic factors in nerve and skin of patients with peripheral neuropathies. J. Neurol. 262, 203-212.

Vendrov, A.E., Madamanchi, N.R., Niu, X.L., Molnar, K.C., Runge, M., Szyndralewiez, C., Page, P., Runge, M.S., 2010. NADPH oxidases regulate CD44 and hyaluronic acid expression in thrombin-treated vascular smooth muscle cells and in atherosclerosis. J. Biol. Chem. 285, 26545-26557.

Wan, W.H., Hollins, F., Haste, L., Woodman, L., Hirst, R.A., Bolton, S., Gomez, E., Sutcliffe, A., Desai, D., Chachi, L., Mistry, V., Szyndralewiez, C., Wardlaw, A., Saunders, R., O'Callaghan, C., Andrew, P.W., Brightling, C., 2016. NADPH oxidase 4 over-expression is associated with epithelial ciliary dysfunction in neutrophilic asthma. Chest 149 , 1445-1459.

Wilkinson-Berka, J.L., Deliyanti, D., Rana, I., Miller, A.G., Agrotis, A., Armani, R., Szyndralewiez, C., Wingler, K., Touyz, R.M., Cooper, M.E., Jandeleit-Dahm, K.A., Schmidt, H.H., 2014. NADPH oxidase, NOX1, mediates vascular injury in ischemic retinopathy. Antioxid. Redox Signal. 20, 2726-2740.

Williams, S., Hamil, N., Abramov, A.Y., Walker, M.C., Kovac, S., 2015. Status epilepticus results in persistent overproduction of reactive oxygen species, inhibition of which is neuroprotective. Neuroscience 303, 160-165.

Yowtak, J., Wang, J., Kim, H.Y., Lu, Y., Chung, K., Chung, J.M., 2013. Effect of antioxidant treatment on spinal GABA neurons in a neuropathic pain model in the mouse. Pain 154, 2469-2476.

Zelenka, M., Schafers, M., Sommer, C., 2005. Intraneural injection of interleukin-1beta and tumor necrosis factor-alpha into rat sciatic nerve at physiological doses induces signs of neuropathic pain. Pain 116, 257-263. 